\title{
Chapter 4: \\ Organized Action: Agency, (In)capabilities and Means
}

\section{Organized Action as Part of the Technicity of Action}

One of the main features of human life is the organization of interaction. Our social existence simply cannot be imagined without clubs, companies, religious communities, protest movements, schools, factories, administrations, hospitals, etc. It is thus quite evident that organized action has to form part of a study on human capabilities and the means by which people act.

Before we go further, I need to explain why I speak about "organized action" from the outset. ${ }^{1}$ Using this term allows me to keep action central to my approach, so as to gain a view on the full variety of a specific aspect of action. On the one hand, organized action is a much more general phenomenon than actions within organizations such as bureaucracies or companies, which are formalised under the name "organization". On the other hand, the varieties of organized action display a range of levels of formality, which is important to account for if one wants to understand what is "organizational" about them. Both of these points may be illustrated with the example of the "informal economy"2: its informality is also a version of organized action, albeit less structured than "organizations" in the narrower sense.

While my approach remains a theorizing of action, I will not refrain from using the word "organizations". This is not merely due to convention. Part of the discussion consists of advancing an action theoretical ontology of organizations - variations in the size and complexity of organizations can only be properly accounted for by studying them as extensions of organized action. This first approximation of organized action is required in order to demarcate the theme of the current survey. I defend two theses. The first is that organizations, as the outcome of and basis for organized action, have a specific agency, of which the ac-

1 I originally derived the notion of "organized action" from Crozier and Friedberg, cf. Michel Crozier and Erhard Friedberg, "Organizations and collective action," in Studies of Organization in the European tradition, eds. Samuel B. Bacharach, Pasquale Gagliardi and Bryan Mundell, (Greenwich: Jai Press, 1995), 77. However, since I could not make peace with their "methodological utilitarianism," I restrict my reference to their concept to the two formal traits of organized action that follow.

2 Cf. the short retrospective on this notion in Chris Hann and Keith Hart, Economic Anthropology. History, Ethnography, Critique (Cambridge, and Malden, MA: Polity, 2011), 112-16.

Ә OpenAccess. (c) 2021 Ernst Wolff, published by De Gruyter. (cc) BY-NC-ND This work is licensed under the Creative Commons Attribution-NonCommercial-NoDerivatives 4.0 License.

https://doi.org/10.1515/9783110725049-006 
tion theoretical concepts used here can give an account. The second thesis is that organized interaction is characterised by structures of capacity and incapacity comparable to those of individual action and studying these (in)capabilities reveals the technicality of collective action, of which the utilization of technical means is an important part.

At first sight, Ricœur's later practical philosophy could be immediately helpful in thinking through this dimension of human interaction. In the previous chapter, we saw how he sought an appropriate way to articulate the individual capability to act and the institutional embeddedness of action (see Chapter 3, $\S 1)$. Agents' capabilities remain mere potential until they are "activated" in interaction with others. The notion of "others" is differentiated into an interpersonal form (in I-you relations) and an institutional form (in I-it relations).

Yet, one soon realizes that, on its own, this schema remains inadequate to allow us to grasp the specificity of organized action. There are two reasons for this: the understanding of the "other" and the view on "capability":

1. Organized action involves face-to-face interaction and the mediation of anonymous institutions, but the other encountered in organizations cannot be reduced to either of these forms, or to a combination of them.

2. Organized action represents a form of human capability that would be distorted by reducing it to individual capability (and this applies even when we take into consideration the institutional embeddedness of this capability). The kind of capabilities concentrated by organized action are just as distorted when the means of individual and collective action are not accorded due attention.

Nonetheless, I would argue that this is not a dead-end for the question of the hermeneutics of human capabilities and organized action. Quite the contrary. In continuity with the previous chapters, I can now outline the place of organized action in my broader examination of the technicity of action. To do so, I work on the two shortcomings just mentioned.

1. I start by clarifying my view on the specificity of organizational interaction, this "intermediary" between I-you and I-it: it can be wider and more formal than interpersonal relations, taken in isolation, and can be more restricted and more personal than anonymous society-wide institutions. Understanding this intermediary relation will improve our understanding both of who the subject of organization is and of the sense in which agency may be ascribed to organizations. To be clear, I need to establish two things. First, what and how are the relations between people that account for the establishment and maintenance of an organization? Second, in which way may we attribute agency to the organization? The attribution of agency to the or- 
ganization is a condition for the next shortcoming that I address. It turns out that fragments from Ricœur's own work provide stimulating material to advance this point.

2. Next, having established established what the agency of organizations consists of, I can ask how the relation of capability/incapability applies to organizations. The exposition on capabilities/incapabilities in the previous chapter serve as guide, but I am not insinuating that organizations are just individual agents writ large. I will highlight the question of relating (in)capabilities and means of action as part of this discussion.

It is perhaps in order to circumscribe the limits of this discussion - I do not claim to have digested the mountains of sociological and managerial studies on organizations. ${ }^{3}$ My focus remains the place that organizations deserve in my broader exploration of the capabilities and means of action.

\section{Organized Action and the Agency of Organizations}

Before embarking on our examination of collective (in)capabilities, we first have to clarify the tricky term "collective". Admittedly, a thoroughly systematic treatment of this question is absent from Ricœur's work, but it nevertheless contains a number of passages in which valuable insights into the phenomenon of organized action are given. This can be amply demonstrated by drawing on five relevant examples: (1) the theorizing of the representation of social collectivities under the term of "participatory belonging" (appartenance participative) in Time and Narrative 1, (2) the notion of the institution in Oneself as Another, and, (3) in the same book, the notion of practices as adopted from MacIntyre,

3 Some helpful guides are the twin volumes by Paul S. Adler, The Oxford Handbook of Sociology and Organization Studies: Classical Foundations (Oxford: Oxford University Press, 2010), and Paul S. Adler, Paul Du Gay, Glenn Morgan, and Michael I. Reed, The Oxford Handbook of Sociology, Social Theory, and Organization Studies: Contemporary Currents (Oxford: Oxford University Press, 2014), as well as Richard W. Scott and Gerald F. Davis, Organizations and Organizing: Rational, Natural, and Open System Perspectives (Upper Saddle River, NJ: Pearson, 2007). Other useful sources are Walter W. Powell and Christof Brandtner, "Organizations as Sites and Drivers of Social Action," in Handbook of Contemporary Sociological Theory, ed. Seth Abrutyn (Cham: Springer, 2016), 269-92; Peter Preisendörfer, Organisationssoziologie. Grundlagen, Theorien und Problemstellungen, 4th ed. (Wiesbaden: Springer VS, 2016); Alfred Kieser and Mark Ebers, eds., Organisationstheorien, 8th ed. (Stuttgart: Kohlhammer, 2019). From a behavioural perspective see Stephen P. Robbins and Timothy A. Judge, Essentials of Organizational Behavior, Global 17th ed. (Upper Saddle River, NJ: Pearson Prentice Hall, 2017). 
(4) the idea of an advisory team as used occasionally in Ricœur's reflections on medical ethics, and (5) the hermeneutics of "social capabilities" in The Course of Recognition. ${ }^{4}$ The challenge in exploring these five instances lies in not only doing justice to them in their quite divergent contexts, but also testing the possibility of a synthesis of the insights gleaned from them.

\subsection{Entities of Participatory Belonging and Institutions}

What is the epistemological status of the entities of collective action, the "social entities"5 that we encounter in historiography and the social sciences? In Time and Narrative, Ricœur argues that these entities share the trait that a multitude of people participate in their formation and maintenance - they are entities of "participatory belonging". ${ }^{6}$ In social scientific research, such entities are embedded in causal explanations. One may call this kind of causal chain the "quasiplots" of causal explanation. The social entities may thus also be called "quasi-characters". Such "quasi-characters" cannot be broken up into a "dust cloud of individual actions" - in other words, one cannot trace exhaustively the contribution of each individual person's action to the formation of the social entity. While doing similar work as Coleman's bathtub, ${ }^{9}$ the specificity of Ricœur's position resides in the narrative character that he ascribes to social entities and the hermeneutic circle by which agents appropriate these entities understandingly as they belong participatively to them.

Now, although these quasi-characters cannot be de-composed to their constituent participators, they do contain "indirect references" (références obliques)

\footnotetext{
4 This selection does not mean that I have exhausted the possibilities in Ricœur's work for my question. See for instance also archives as social spaces in La mémoire, l'histoire, l'oubli (Paris: Seuil, 2000), 209-230 / Memory, History, Forgetting, trans. Kathleen Blamey and David Pellauer (Chicago: University of Chicago Press, 2004), 166-181.

5 Paul Ricœur, Temps et récit 1. L'intrigue et le récit historique (Paris: Editions du Seuil, 1983), 340 / Time and Narrative. Volume 1, trans. Kathleen Blamey and David Pellauer (Chicago: University of Chicago Press, 1984),193.

6 Ricœur, Temps et récit 1, 321, 340-41 / Time and Narrative 1, 181, 193.

7 Ricœur, Temps et récit 1, 321 / Time and Narrative 1, 182.

8 Ricœur, Temps et récit 1, 340 "indécomposables en une poussière d'actions individuelles" / Time and Narrative 1, 190.

9 On this and other versions of the same schema, see Werner Raub and Thomas Voss, "Micromacro models in sociology. Antecedents of Coleman's diagram," in Social Dilemmas, Institutions, and the Evolution of Cooperation, eds. Ben Jann and Wojtek Przepiorka (Berlin, and Boston, MA: Walter de Gruyter, 2017), 11-36.
} 
to individuals. On this basis it is possible to examine how they are constituted as communities through a method of "questioning back", ${ }^{10}$ also called genetic phenomenology. ${ }^{11}$ While historians and other social scientists are justified in speaking of large-scale quasi-characters, phenomenologists must concern themselves with the real ties between the "members [of]..." or participants composing these quasi-characters. In other words, the phenomenologist has to examine the ontology of the entities of participatory belonging. In this passage of Ricœur's, social ontology consists in

- $\quad$ prioritizing one specific "historical community", namely society, ${ }^{12}$ as well as entities that are most often also of national extension such as the "nation, class, people, community, or civilization". ${ }^{13}$ The three main traits of societies - territorial organization, institutional structure and temporal continuity (taken from Mandelbaum) - refer indirectly to the constituting existence of individuals: dwelling, role-taking and the succession of generations respectively. ${ }^{14}$

- establishing the mode of existence of participatory members to be of the order of action (this corresponds to pre-figuration or mimesis I, discussed in Chapter 2, §3.1), and the mode of existence of quasi-characters to be of the order of narrative (which corresponds to the configuration or mimesis

10 Ricœur, Temps et récit 1, 318 / Time and Narrative 1, 179.

11 Summarised as follows: "It is always starting from the pole of an assumed identity that the work of constitution unfolds behind this pole. Consequently, the work of constitution never begins from a tabula rasa, it is in no way a creation. It is only starting from an already constituted object that one can retroactively, retrospectively, unfold the layers of sense, the levels of synthesis, making the passive syntheses behind the active syntheses appear, and so on.” Paul Ricœur, From Text to Action: Essays in Hermeneutics II, trans. Kathleen Blamey and John Thompson (London: Athlone, 1991), 234 / Du texte à l'action. Essais d'herméneutique II (Paris: Editions du Seuil, 1986), 320.

12 Ricœur, Temps et récit 1, 343 / Time and Narrative 1, 195: "The irreducible object of history is of a societal order".

13 Ricœur, Temps et récit 1, 357 / Time and Narrative 1, 203. Likewise a "governing board, a state, a nation, a people, a class” in Paul Ricœur, Temps et récit 3. Le temps raconté (Paris: Seuil, 1985), 302n21 / Paul Ricœur, Time and narrative. Volume 3, trans. Kathleen Blarney and David Pellauer (Chicago and London: University of Chicago Press, 1988), 207n1 - the first element breaks the rule. This is not yet in itself a sufficient basis for typifying Ricœur's position as a "methodological nationalism". Besides, this notion is itself a complex of difficulties, cf. Daniel Chernilo, "Social Theory's Methodological Nationalism: Myth and Reality," European Journal of Social Theory 9, no. 1 (2006): 5-22.

14 Cf. Ricœur, Temps et récit 1, 349 / Time and Narrative 1, 199. 
$I I$, also discussed in Chapter 2, §3.2). ${ }^{15}$ By implication, the agents often understand each other through these narrative entities. ${ }^{16}$

- laying bare the underlying "ontology of being in common" (ontologie de l'être en commun). ${ }^{17}$ This is done in Time and Narrative $3,{ }^{18}$ where Ricœur writes:

“I am following the broad distinction in Schütz's analysis between a we-orientation and a they-orientation, between a direct kind of orientation and an anonymous form based on typifications [= between interaction of agents and quasi-characters - EW]. Schütz takes great care to nuance this opposition with a careful study (at which he excels) of the degrees of anonymity in the world of contemporaries." ${ }^{\text {"19 }}$

However, despite his praise for Schütz, Ricœur evades a discussion of the "progressive enlargement of the sphere of direct interpersonal relationships to include anonymous relationships". ${ }^{20}$ Still, this ontology of being in common sketched in Time and Narrative 3 reflects the pattern of Time and Narrative 1 , in which the instituting interaction is contrasted with the anonymity of quasi-characters, which nevertheless refers indirectly to the instituting interaction.

Subsequently, in Oneself as Another, Ricœur takes over this basic framework for his social thought. He focuses on the I-you (interpersonal) and the I-it (institutionally mediated) dimensions of human interaction, again at the expense of a

15 Ricœur, Temps et récit 1, 351 / Time and Narrative 1, 200.

16 A similar position is taken by Luc Boltanski, who writes that "a sociology whose object is modelling the way in which social actors fashion society can indeed regard communities (or, in general, collectives) as fictions, but on condition of recognizing that these fictions seemingly have a necessary character and must therefore, at least by this token, find a place in sociological theory." Luc Boltanski, On Critique: A Sociology of Emancipation, trans. Gregory Elliot (Cambridge: Polity, 2011), 36 / De la critique. Précis de sociologie de l'émancipation (Paris: Gallimard, 2009), 65 (my emphasis).

17 Ricœur, Temps et récit 1, 350n1 / The English translation renders it as "ontology of the werelation," Time and Narrative 1, $261 \mathrm{n} 17$.

18 Cf. Paul Ricœur, Temps et récit 3. Le temps raconté (Paris: Seuil, 1985), 203-209 / Time and narrative. Volume 3, trans. Kathleen Blamey and David Pellauer (Chicago and London: University of Chicago Press, 1988), 112-114.

19 Ricœur, Temps et récit 3, 207n1 / Time and Narrative 3, 392n21 (my emphasis). See also Temps et récit 3, 204 / Time and Narrative 3, 302.

20 Temps et récit 3, 204 / Time and Narrative 3, 112. Cf. also Paul Ricœur, Soi-même comme un autre (Paris: Seuil, 1990), 228 and 234 / Oneself as Another, trans. Kathleen Blamey (Chicago, IL: University of Chicago Press, 1992), 195, $200-201$. 
phenomenology of degrees of anonymity in the world of contemporaries for which he praises Schütz.

Instead, Ricœur coordinates these two dimensions of interaction by considering institutions as constituted by power in common, a notion he gets from Arendt. ${ }^{21}$ We will discuss this in greater detail in the next chapter (see Chapter 5 , $\S 2.1 \mathrm{a}$ ), but a few comments on this point are in order here. Power in common enables Ricœur to account for the event by which a plurality of individuals generate institutions and it introduces the social factor of power in institutions. However, Arendt's understanding of action remains artificially detached from "work" and "labour" and thus predisposes Ricœur to give a one-sidedly political view of institutions. ${ }^{22}$ Moreover, the question of the relative stability of action is settled by moving directly from "action in concert" to institutions which buttress actions. In this way, the impression is created that Ricœur's view on the constitution of institutions leans to the individualistic, or even voluntaristic, side.

Yet Ricœur does not believe he has succumbed to individualism, and thanks to the Rawlsian notion of participation/distribution ${ }^{23}$ that he introduces at this point. ${ }^{24}$ Through "participation", action can bridge the gap from the interpersonal level of $I$-you (where all power in common originates) to the societal level of institutions, the $I$-it relations. In short, the notion of participation, firstly, (implicitly) marks the place of a full theory of the degrees of anonymity from the interpersonal to the societal, and secondly, (explicitly) seals the fate of the presumed opposition between the individual and society.

Nevertheless, this solution smuggles in three biases:

- In harmony with the trend in Time and Narrative, Ricœur prioritizes a notion of "society", which he understands to be as extensive as the inhabitants of a country or region, at the expense of a plurality of societies or associations of varying sizes.

- Ricœur's presentation of institutions follows the same trend.

- When Ricœur defines institutions as structures of living together held together by common mores, ${ }^{25}$ this contention remains in harmony with the

21 Hannah Arendt, “On Violence," Crises of the Republic: Lying in Politics, Civil Disobedience, on Violence, Thoughts on Politics and Revolution (San Diego, CA: Harvest/Harcourt Brace Jovanovich, 1972), 103-198, here 143.

22 Nevertheless, he refers to all three terms from Arendt's The Human Condition in Ricœur, Soimême comme un autre, 229n1 / Oneself as Another, $196 \mathrm{n} 38$.

23 See especially Part 2, "Institutions" in John Rawls, A Theory of Justice. Rev. ed. (Cambridge, MA: Harvard University Press, [1971] 1999).

24 Cf. Ricœur, Soi-même comme un autre, 234 / Oneself as Another, 200.

25 Ricœur, Soi-même comme un autre, 227 / Oneself as Another, 194. 
narratological status of the quasi-characters in Time and Narrative 1 in the sense that it is to the detriment of the organizational meaning of the institution.

From these biases arise Ricœur's excessive attention to the two poles of initiating or instituting events of collective action on the one hand, and the already existing, instituted structures on the largest scale on the other - this, at the expense of what binds the two together. What do I have in mind? What is missing here ${ }^{26}$ are - processes of formalisation and codification (and deformalisation and decodification) of the structure,

- the generation and disintegration of teleological structures,

- attention to the introduction of agents into their roles,

- attention to the degree to which agents are mobilised for the accomplishment of collective aims, and

- the mechanisms by which the systems of participation/distribution are maintained.

What is at stake in these five shortcomings is the core of organized action itself, namely the degree of integration, formalisation and stability of varying scales of acting in common.

\section{Interim Conclusion: Individual and Collective Agency of Organized Action}

Despite the limitations indicated, the two texts discussed just now are instructive regarding the agents of organized action.

In reflecting on organized action, it is always possible to zoom in on the individual agent, who interacts with others. Even on this scale, organized action is structured by $I$-it relations. ${ }^{27}$ But the individual agent's relations to others in organized action has another dimension, corresponding to the degrees of anonymity between direct interpersonal and completely anonymous institutional relations. These intermediate kinds of relation vary and fluctuate according to the five factors listed at the end of the previous paragraph. How these varying mediations of interaction impact on the (in)capabilities exercised by individuals acting in an environment of organizational counterparts, and of organizational

26 Here I borrow from Erhard Friedberg, "Les quatre dimensions de l'action organisée," Revue française de sociologie 33, no. 4 (1992): 531-57.

27 Although these are not saturated by institutional relations, as Laurent Thévenot points out in meticulous studies in L'action au pluriel. Sociologie des régimes d'engagement (Paris: La Découverte, 2006). 
infrastructure, can be described using the exposition of (in)capabilities in the previous chapter (see Chapter 3, §2). Such variations of individual action in organization can be illustrated, for instance, in considering networking, which is a major contribution that individuals make to their organization. Networking as interaction can be facilitated or obstructed by an organization; it can happen more or less formally; it could be more inside-inside oriented or more inside-outside oriented. Each time the organization has an impact on the precise character or "adverbial increments" of this type of networking interaction. ${ }^{28}$

More important still is the perspective opened on collective action. If we accept Ricœur's view on the constitution of entities of "participatory belonging”, then one has to consider the quasi-character formed by organized action to be "organization" in the broadest sense. This view facilitates a complex view on organizations. Consider, in particular, the recurrent claim that "[o]rganizations are made up of individuals pursuing a common goal, such as producing a good or service or advocating for some cause". ${ }^{29}$ It would be much more circumspect to say that, (a) in as far as people consent to have their efforts taken up in a broader movement of organized action, they do indeed participate in the pursuit of that organization's goals, and yet, (b) many people are in organizations in pursuit of many other goals (and those of the organization may in extreme cases be irrelevant to them). Moreover, one can say that (c) all their activities and the unintended consequences of their actions contribute to shaping the organization, but that finally, (d) the organization is not simply the overlap of individual projects. Ricœur's idea of participatory belonging can account for all of these facts. ${ }^{30}$ On the strength of this conclusion, I claim that organizations, as quasi-charac-

28 Cf. Powell and Brandtner, "Organizations as Sites and Drivers of Social Action,” 281, 286. On “adverbial increments", see again Chapter 3, §2.2.

29 Powell and Brandtner, "Organizations as Sites and Drivers of Social Action,” 270.

30 This is not without political relevance: consider what organizations do to people, how sometimes people are forced to participate. Or conversely, consider the fact that organizations need a minimum of buy-in (power in common, if you will) to function.

In his work before Oneself as another Ricœur made abundant use of Max Weber's action theory (coupled with Husserl's phenomenology of intersubjectivity), cf. Paul Ricœur, "Hegel et Husserl sur l'intersubjectivité" in Du texte à l'action, 311-34) / "Hegel and Husserl on intersubjectivity" in From Text to Action, 227-45. This provides material for a direct comparison with Thomas Schwinn's Weberian piece, "Interaktion, Organisation, Gesellschaft. Eine Alternative zu Mikro-Makro?," in Interaktion - Organisation - Gesellschaft revisited. Anwendungen, Erweiterungen, Alternativen. Sonderheft der Zeitschrift für Soziologie, eds. Bettina Heintz and Hartmann Tyrell (Stuttgart: Lucius \& Lucius, 2015), 43-64. However, despite the similarity in structure with what I reconstruct here from Ricœurian material, because the 1990 book relativises the significance of Weber for Ricœur, I do not engage with Schwinn's position. 
ters formed by organized action, acquire a functioning that is not reducible to a myriad of individual courses of action and practices. I will call this the (quasi-) agency of organizations.

Having thus established the specificity of organizations as collective agents, one may venture that this agency has its own, corresponding (quasi-)capabilities through which organizations can speak, act, narrate, be responsible, remember and promise. The specific qualities of these capabilities vary according to the specific characteristics of each form of organized collective action. And one may already assume that for each of these quasi-capabilities there is as corresponding quasi-incapability (a point I will demonstrate later in this chapter).

Having provisionally clarified the two modes of agency involved in organized action, let us see what Ricœur can teach us in respect of what agents do and how they act in organizations.

\subsection{Practices and the Example of Advisory Bodies}

As part of a "revision of the concept of action", ${ }^{31}$ Ricœur examines composite units of action such as professions, games, arts. ${ }^{32}$ Practices are "units of configuration" 33 and are structured by "embedding relations". ${ }^{34}$ Complex actions are governed by "laws of meaning" "35 and are made up of constituent actions that follow "constitutive rules". ${ }^{36}$ These rules imply that actions can be seen as actions of a specific practice, and that they can clearly be recognized and acknowledged as such. Furthermore, practices are interactions, or even "internalized interaction", ${ }^{37}$ in which agents take each other into account in the form of competition, cooperation, conflict, etc. ${ }^{38}$ Agents also learn practices in relation to and with others, in traditions of education. ${ }^{39}$ Practices are then embedded in life plans (plans de vie), such as family life, professional life, or recreation and these in turn are embedded in the narrative unity of one's life.

31 Ricœur, Soi-même comme un autre, 181 / Oneself as Another, 152.

32 Ricœur, Soi-même comme un autre, 186 / Oneself as Another, 157.

33 Cf. Ricœur, Soi-même comme un autre, 182 / Oneself as Another, 153.

34 Ricœur, Soi-même comme un autre, 182 / Oneself as Another, 153. The published translation renders "relations d'enchâssement", as "nesting relations".

35 Ricœur, Soi-même comme un autre, 182 / Oneself as Another, 154.

36 Ricœur, Soi-même comme un autre, 183 / Oneself as Another, 155.

37 Ricœur, Soi-même comme un autre, 185 / Oneself as Another, 156.

38 Ricœur, Soi-même comme un autre, 185 / Oneself as Another, 156.

39 Ricœur, Soi-même comme un autre, 185/ Oneself as Another, 156. 
Clearly, Ricœur's borrowing from the Aristotelian tradition is of interest to the current question. Yet the exact nature of this inchoate theory of organized action has to be qualified.

On the positive side, practices allow individual agents to attest to their capabilities when these are activated in the agents' interaction with close-by others (I-you, e.g. in interactions that involve collaboration, conflict, etc.), and others far away (I-it, e.g. in through traditions). ${ }^{40}$ Through practices, instituted interaction on scales other than that of national societies are introduced in the discussion. Therefore, practices could be considered to fill the place of the "degrees of anonymity" as Schütz calls them, in as far as practical roles account for the particular mediations that constitute the organizational self and other. In short, the exploration of practices shows the way to a fuller understanding of institutionalization and of the alterity involved in organized action.

On the negative side, the concerns of Study 6 of Oneself as Another steer Ricœur to focus on the structure of embedding: actions - practices - life plans narrative unity of a life. In this way, a series of other components of organized action are lost from view: agents' belonging(s) to different organized complexes, the relationships between different organized action complexes, the mode of existence of rules and configurations of practices, as well as the reasons for their inertia and resistance to change in organizations, the cumulative adverse effects of actual practice, and so on. Other components of organized action remain underdeveloped: the degrees of formalisation (present in the relationship between tradition and innovation), the specification of organizational otherness (even if the notion of "internalised interaction", and the forms of interaction - competition, cooperation, conflict - point to it), conflicts over the constitutive rules, ${ }^{41}$ etc. Yet, if narrative identity is essential in connecting the descriptive to a normative approach to action (as Ricœur argues in Oneself as another, Study 6), it is surprising that Ricœur presents the practising of practices as coordinated only in the narrative unity of a life and its quest for being good, and not in the narrative unity of organizations in and with which people live and which has a direct influence on institutions. One misses out on important gains that can be had from the previously examined passages too, in particular the notion of collectivities as quasi-characters. In Ricœur's discussion one finds, for instance, the practice of the farmer without reference to the quasi-character, the farm (the example of the practice of judging without looking at a court of law illustrates the problem even more clearly).

40 See again Chapter 3, §1, Figure 1.

41 Ricœur, Soi-même comme un autre, 207 / Oneself as Another, 176. 
Together, these two points confirm that Ricœur's discussion of practices is about the practices of individuals acting in organized contexts, but not about the actions of organizations. This point may be missed if one considers an apparent counter-example, where the hermeneutics of the capable human suitably accommodates reflection on the action of a small organization. Concluding his discussion on "prudential judgement" in bio- and medical ethical cases, Ricœur points to the fact that decisions of practical wisdom can be prepared with the full benefit of advice and debate with specialists in the field, in other words, as groups, not as individuals. ${ }^{42}$ Ricœur argues that doctors, like judges, make their judgements supported by an advisory body (cellule de conseil). ${ }^{43}$ What is this advisory body then, if it is not diverse social role players, each contributing a specific competence? To paraphrase in terms close to those in Time and Narrative 1: the advisory body is a quasi-character, however, one so small that its actions can to a great extent be decomposed into the actions of the individuals who constitute it and to which this quasi-character always refers indirectly.

However, the point remains that this case is an outlier that cannot be generalised to all organized action. But elsewhere one does find Ricœur reflecting on collective agency. Let me turn to such a case.

\subsection{Social Capabilities}

In the second study in The Course of Recognition, Ricœur revisits his hermeneutics of the "I can" and extends it with an excursion on what may be called a hermeneutics of the "we can", which he identifies in social capabilities and practices. Whereas individuals are capable of affirming reflexively their ability to act through attestation, collectivities do so through public evaluation and approval, ${ }^{44}$ through ethico-legal justification, or disputes and claims about social justice.

The identity of collective actors is reflected by symbolic mediation in representations of the practices as competences for social action. ${ }^{45}$ The identity of social entities is the (disputable) agreement that coordinates social actions and

42 Ricœur, Soi-même comme un autre, 318 / Oneself as Another, 273 and Paul Ricœur, Le juste 2 (Paris: Esprit, 2001), 252-253 / Reflections on the just, David Pellauer, trans. (Chicago: University of Chicago Press, 2007), 219-220.

43 Ricœur, Le juste 2, 253 / Reflections on the Just, 220.

44 Paul Ricœur, Parcours de la reconnaissance (Paris: Stock, 2004), 215 / The Course of Recognition, trans. David Pellauer (Cambridge, MA: Harvard University Press, 2005), 134. 45 Ricœur, Parcours de la reconnaissance, 219-20 / Course of Recognition, 137-38. 
practices, even when the relevant identity is still under construction. Ricœur implicitly revisits the question of the ontology of collectivities in a way close to that of Time and Narrative: agents and their coordination in collective action do not have the same ontological status - collective identity is narratological (Time and Narrative) or representational (The Course of Recognition), and in both cases, they are in the process of being established by agents' actions. This difference between the two ontologies is reflected in the "interplay of scales"46: by concentrating on the micro level, one gets a glimpse of the strategies by which agents attempt to reduce the unpredictability of events; by focusing on the macro level, one observes the long-term anonymous structures and constraints which nevertheless stand under the influence of social action. ${ }^{47}$ The difference of ontological status, reflected in the interplay of scales, is responsible for the fact that social capabilities cannot be recognized by direct attestation, but are recognized rather by "second-order reflection reconstructing them". ${ }^{48}$

An illuminating example of this complex of ideas is identified by Ricœur in Amartya Sen's thought on "rights to certain abilities". ${ }^{49}$ In this valuable expression are linked "capabilities" - which refer to the positive freedom of each individual for his/her life choices (as opposed to both negative freedom and exclusively self-interested action) - and "rights", that is, claims in the name of social justice. If one follows Sen and Drèze's scientific finding that an improvement in the conditions for the exercise of positive freedom (capabilities) actually prevents famines from occurring, then one could say that preventing famines is a manifestation of a capacity to act, that it is a collective capability, that it is good to be capable in this way, and that it is good that this capability be guaranteed (for example, in the form of rights), since it makes the realization of social justice possible. Thus, it is not a question of directly attesting an individual capability, the "I can", but of a "second-order reflection reconstructing" a social capability, of the "we can" in the form of a public appreciation and approval, ar-

46 Ricœur, Parcours de la reconnaissance, 220 / Course of Recognition, 139, the phrase is borrowed from Jacques Revel.

47 Ricœur, Parcours de la reconnaissance, 221 / Course of Recognition, 139.

48 Ricœur, Parcours de la reconnaissance, 223 / Course of Recognition, 140.

49 Ricœur, Parcours de la reconnaissance, 228 / Course of Recognition, 144. See also Paul Ricœur, La critique et la conviction. Entretien avec François Azouvi et Marc De Launay (Paris: Calmann-Lévy, 1995), 187 / Critique and Conviction. Conversations with François Azouvi and Marc De Launay, trans. Kathleen Blamey (New York, NY: Columbia University Press, 1998), 123 for the connection with these ideas and "collective guilt" and "collective memory". Another elaboration of social imaginary that could be linked to the current discussion is that of ideology and utopia in Ricœur's Lectures on Ideology and Utopia, ed. George Taylor (New York, NY: Columbia University Press, 1986). 
ticulated in the claim of a right. This right, when it is claimed, would be, according to Ricœur's argument, the second degree "attestation" or reconstructed representation of a social capability to act. Using some other terms considered here, it could be said that if a famine does occur, it would be because, from the micro point of view, individual actors are not able to exercise their life choices in order to obtain food; or because, from the macro point of view, the absence of rights creates a social injustice, preventing the population from feeding itself.

\subsection{Scales of Organized Action, its Capabilities and Means}

We have now been able to develop further the findings of the "interim conclusion". We have seen that the subject of organized action is, on the one hand, the self, who can attest to his/her own capabilities to act in interaction with others under organized conditions, on the other hand, quasi-characters ("organizations") of varying sizes and complexities whose capabilities are identified in a work of reconstruction (in fact, the collective agent itself is derived from the demonstration that collective capabilities have been used). It is therefore no contradiction when Powell and Brandtner ${ }^{50}$ attribute agency to organizations (as they do when they refer to organizations as equalisers, stratifiers, stabilisers, movers, shakers, etc.), while passing in review, amongst others, micro behavioural or ethnomethodological studies on individuals in organizations. Ricœur gives us a means by which to coordinate these two forms of discourse.

Yet, up to The Course of Recognition, Ricœur maintains his preferential treatment of the two extremities on the spectrum of the interplay of scales. ${ }^{51}$ Accordingly, we may sometimes focus on the individual agents, their interaction, their practices, and the constraints to their action, and sometimes on the largest collective agents, which do not exist without the individual actors, but still cannot be broken up into a "dust cloud of individual actions". It is then up to us to insist on the whole range between these two ends of the spectrum of scales and on the variety of collective actors and organizations it covers.

But how can one get access to this variety? Ricœur's understanding of the embedding of actions into practices may give us some direction, but we have al-

50 Powell and Brandtner, "Organizations as Sites and Drivers of Social Action”.

51 This is also Ricœur's way of coordinating what David Lockwood called "systems integration" (in Ricœur's terms, the formation and relation between quasi-characters) and "social integration" (in Ricœur's terms, the interaction of individuals with other individuals and with organizations). 
ready noted the limitations of such an approach. I would now like to suggest an alternative..$^{52}$

(A) This alternative starts out from the basic components describing what organizations of various scales are. Following the classic textbook presentation of Scott and Davis, ${ }^{53}$ organizations consist of transactions between people, their work with technology, the organization's formal organization and its informal organization - together driven by an almost external factor, namely goals. With my previous chapters in mind, one cannot fail to notice that each of the four components has a technical dimension: the habitus of the participants, the work they do with available technologies, the technical "software" of the organizational structure (both formal and informal). Without these, strategic aiming at goals and ends would not mean much. While Scott and Davis have more formally institutionalized organizations in mind, it would be possible to demonstrate that their model applies to all organized action, even if in some cases, this would be less evident than in others.

(B) But this point would remain almost trivial, if we do not consider how organizations act in pursuit of their goals (the fact that the action(s) of organizations cannot be reduced to the mere pursuit of goals and that they do not always achieve the goals they pursue, need not detain us now). Pursuing its goals, an organization takes on an organizational structure that is supposed to facilitate the efficient attainment of those goals. Robbins and Judge list six typical traits of organizational structure, ${ }^{54}$ as ways of organizing the four components of the organization (and thus, following our previous point, the technical capabilities and means deployed in the organization). The six traits are work specialisation, departmentalization, chain of command, centralization and decentralization, formalisation and boundary spanning. Note that each of these traits of organizational structure allows for a spectrum of variable increments (for instance, the chain of command and reporting may restrict sensitive information to a larger or smaller group of collaborators and the authority to make decisions may be shifted higher or lower on the hierarchy; or a greater or smaller number of roles may be created to cross the boundaries of formalised working groups with greater or lesser freedom to exercise their own initiative). The ways in which they vary determine the features of an organization and consequently

52 This remains true to the spirit of Ricœur's phenomenological studies, which proceed from an examination of the what, through the how, to the who. However, this procedure is based on the phenomenology of individual agents, not collectives. In another way, I remain true to his hermeneutics, namely by advancing via a detour through scientific work outside of philosophy.

53 Scott and Davis, Organizations and Organizing, 20, discussion 20-25.

54 Robbins and Judge, Essentials of Organizational Behavior, 276-82. 
has a vital influence on what the organization is able to do and how it will act. Although subject to change, these traits may be relatively stable (it is the point of intersection between these changing traits that identifies the organization for what it is and reflects the ways it acts.) This means that by comparing the cluster of traits of organizations, we may also identify the key differences between them and (partially) account for the different ways in which they act. But organizational structures are also modified, which means that the identity of an organization changes over time, and allows us to account for gradual change in the appearance and action of each organizational quasi-character.

These two considerations (the four components of organizations and the six traits of their structure) combined, give us a first clue as to how one could account for the variety of organizational agents as subjects of "social capabilities" (in the terms of The Course of Recognition). The particular traits of each organization's structure become the pieces of a mosaic which reflect the actional capability of the collective. However, this does not mean that the organization's structure equals its capabilities, since, up to this point, we have left out the real-life action (power in common) which invigorates the organization. Once this factor is added, the organizational structure may serve as a means by which to converge individual agency with collective agency and to represent that claim to collective agency (as the claim to rights does for social capabilities, according to Ricœur's reading of Sen). Each time an organization delivers a service or a product, this retroactively confirms the claim to that organization's having collective agency, corresponding to the variations of its traits.

From their side, the agents bring more to an organization than just the power to act in harmony with the relatively bulky and slowly changing features of the organization (solidity due to the consolidation of certain practices or the use of heavy and expensive equipment). The individual agents' action(s) may vary over the course of a day, or over a cycle of financial reporting, differ between individuals, fluctuate according to team spirit, change according to the institutional culture, etc. ${ }^{55}$ All these variables have an impact on the way in which interacting individuals continually institute their organization.

Finally, having made these distinctions clear for the purpose of greater precision, we have succeeded in getting a better grasp of the rich variety of interactions and collective action that lie between face-to-face interaction and the anonymity of institutions.

55 Nor should the fact that we can give a name to an organization as a quasi-character give the impression that the frontiers are sharply drawn or stable. 
(C) Individual agents' continual buy-in or cooperation thus remains a necessary condition for organizational agency. Whereas the variations in agents' behaviour in organizations can be described, often people have an interest in controlling it, in as far as the organization serves to pursue a set of aspirations. Hence, we also need to consider interventions in view of steering organizational behaviour. Drawing on insights from agency theory in organizations, Preisendörfer distinguishes four "instruments for disciplining agents": ${ }^{56}$ (1) direct behavioural control, (2) rewards that depend on results, (3) bonding or guarantee arrangements, and (4) improvements to the information system. Two things should strike us in these strategies. Firstly, they are a means by which to change action. Secondly, the variables that they can introduce into action can have an impact on the agents' biological body, their trained body, their coordination of actional qualities, the coordination of their interaction with others or their use of means or technologies - in short, any of the five aspects of human (in)capabilities discussed in the previous chapter (and summarised below).

Two further consequences of this chain of thought (Points A to $\mathrm{C}$ above) have to be spelt out. Firstly, speaking about interventions in organizational behaviour (Point C), we consider interventions in the (in)capabilities of agents as individuals participating in organization. One would expect that, as the scale of organization increases, our ability to break up the cumulative effects of such changes in behaviour or interventions on the individual agents' change of behaviour would decrease. This then again raises the question about the nature of collective agency, which I discuss next. Secondly, attempts to control individual agents' action (Point $\mathrm{C}$ ), through the structuring characteristics of organizations (Point B), may be expected to change the whole organization (Point A) in its likely behaviour, in what it is able to achieve, and the limits of that achievement. Or one may simply claim that organizations as collective agents have their own capabilities and incapabilities (which are not reducible to those of the individuals who act in them). This is what I would like to develop in the next section.

\section{Capabilities and Incapabilities of Organizations}

Having thus clarified the question of the subject of organized action, the time has come to return to the original question: how, then, are we to understand the relationship between capability and incapability in organized action? A short recapitulation at this point may help to contextualise the discussion.

56 Preisendörfer, Organisationssoziologie, 119-24. 
Under the term "technicity", I have studied one of the aspects of human interaction, namely that which involves the conscious or unconscious exercise of dispositions and capabilities, often through the use of specific means. Reflecting on the technicity of capabilities, I discovered the importance of a very specific notion of incapability. This was discussed in the previous chapter. I use the term "incapability" such that the negative prefix "in-" refers neither to doubting the capacities attested to, nor to ignoring capabilities, nor to a lack of capabilities in fragility or suffering - it simply points to a weak notion of incapability as a constant companion of capability: the incapability in question shows itself only as correlated to capabilities, and in action. This approach provides a way to get closer to the ever unattainable goal of a theoretical grasp of the action as action. More specifically, it is by considering how the event of action correlates capability and incapability that one can, firstly, see exactly what is done (and what is not done) or the degree to which one is able to do something, secondly, discern the kind and level of competence of an agent to do something in particular, and thirdly, open a useful window on the means that intervene in the execution of actions.

To visualise this role of incapability in action better, let us briefly recall its five dimensions, as discussed in Chapter 3, §2.1.

1. Capabilities are exercised by the biological body, which is never completely mastered. Therefore, when exercising his/her physical capabilities, the agent will simultaneously be confronted with the incapability completely to control his/her acting body. This incapability characterises the particular manifestation of action no less than the capability does.

2. Insofar as we have abilities to do things, these acquired abilities dispose us to do something in particular and in a particular way. It does not always become impossible to do it otherwise, but in practice it becomes more difficult: it is less likely that we will act against our dispositions, and in this sense, represent a weak incapability.

3. By acting, we combine actions. However, even if the capable agent can combine his/her actions in many different ways, not all combinations are practically feasible; one is incapable of performing certain combinations. In consequence, the way in which actions are finally combined speaks as much about capabilities as about incapabilities.

4. Similarly, the coordination of one's actions with those of others imposes limits on our actions: although we may be able to do something with others, this action receives part of its meaning from the qualities of interaction that we are, by definition, incapable of producing ourselves. 
5. The mediation of our actions by means has an effect of simultaneously increasing and reducing our capability. In action, the means amplify the distinction between what I can and cannot do.

The individual capable human in an organized context essentially displays the (in)capabilities just recalled. The five dimensions of individual (in)capability will now be used as a heuristic framework to reflect on the collective (in)capabilities of organizations. When we speak about (in)capabilities, the whole series of capabilities to which they correspond (such as saying, doing, narrating, imputing, remembering and promising) is implied, even if this is not illustrated in the examples that follow.

1. The organization as a quasi-character constantly refers, obliquely, to the agents whose power-in-common institutes the organization. However, its existence and therefore its capacity to act is, at its inception, ephemeral. Without a certain formalisation (and technical support, see Point 5. below), it is incapable of ensuring its action in the long term (see Points B and C above). Even then, the management of organizations remains incapable of completely mastering the common power that institutes the organization. Moreover, even if it is true that organizations need common action to maintain themselves (and this is whence their agency comes), it is impossible to keep this fact permanently in mind - the formalisation of organizations leads to the forgetting $^{57}$ of the power-in-common, that is, to the incapability to remain in the act of instituting, and to taking collective action for granted. A number of phenomena testify to this limitation of capability: the formation of informal structures, nepotism and to some degree the organizational culture, etc. However, efforts to steer this force of organized action lead to varying degrees of "structural inertia", ${ }^{58}$ which may in turn limit the organization's capabilities, and notably its ability to change.

2. The internal structuring of each organization makes it easier for this quasicharacter to do certain things, and in certain ways (see Point B above). It is possible to maintain this claim without committing a teleological reduction of the organization: the organization is what facilitates $\mathrm{X}$, as a result making Y more difficult to execute; it is what predisposes the quasi-character to do A in an $\mathrm{A}^{1}$ way, so much so that it becomes improbable, even impossible, to do $A$ in an $\mathrm{A}^{2}$ way. Moreover, like individual agents, organizations can exercise their capacity to act, or even achieve intended outcomes, only by surrender-

57 On "forgetting” as a technical term in Ricœur’s social thought, see Chapter 5, §2.1c. 58 Robbins and Judge, Essentials of Organizational Behavior, 318. 
ing to the incapability of avoiding all unintended adverse effects. Finally, organized action may well intensify people's efforts to set goals, to plan and to maximise the outcome for their efforts, but this still does not mean that organizational agency (individual or that of the organization) has to be construed according to the lines of rational action theory or utilitarian action theory. ${ }^{59}$

3. Organizations not only combine the effort of different members and groups, but also combine different actions or adverbial determinations. Not all combinations are possible. This seems to me, for instance, to be the dilemma faced by the Catholic Church at the time of Benedict XVI: finding an answer to how to convince the world once again of the greatness and weight of the Church as a millennial institution, while at the same time presenting her as a humble servant of humanity. Another instance is the challenges faced in management regarding how to balance the organizational strategies of innovation and cost-minimisation, when they ideally require organistic and mechanistic structuring of the organization respectively, and how to find a compromise between this balance and a third strategy, that of imitation, which requires a combination of the two forms of structuring ${ }^{60}$ In the course of action, the exercise of capabilities results in the manifestation of incapabilities - the specific relationship between capability and incapability revealing the degree of competence of an organization in carrying out a set of actions.

4. Similarly, the ability of an organization to act in one way but not another, which depends on how it coordinates its action with that of other organizations. A crowd that is not at least minimally organized is not able to assert itself in the face of other social forces (think, for instance, of a group of labourers engaged in a dispute with the managerial powers of the sector of industry they work in ${ }^{61}$ ). Once their power in common is consolidated by the symbolic mediation of a claim considered just or good, a unification of individuals may occur (however, at the price of excluding opposition, with the concomitant risk of weakening support for the group). In turn, this assessment of action (or, as Ricœur calls it, "imputing” action as praiseworthy

59 One could get this impression, for instance, from Preisendörfer's exposition on agency theory in the sociology of organizations, Preisendörfer, Organisationssoziologie, 114-29. On this point, see again the distinction between primary and secondary technicity in Chapter $3, \S \S 3.1$ and 3.2.

60 This example is derived from Robbins and Judge, Essentials of Organizational Behavior, 289. 61 In Chapter 8, §3.1 an example is explored in detail. 
or blameworthy to agents ${ }^{62}$ ) makes the formation of coalitions easy or difficult (the group becomes capable of some coalitions, while others become difficult). Also, the group becomes unable to reconcile its claim to fight for a cause with certain behaviours (such as whether the ends justify the means). Finding a trade-off between pre-election promises and post-election coalition formation illustrates the point - Belgian politics offering a wealth of instances. Finally, the organization's adopted strategy has to be coordinated with the broader social environment (its means, its expectations, etc.). The relation between organized action and its social environment shifts the degree of (in)capability of the organization, in relation to the capacity, volatility and complexity of the environment. ${ }^{63}$

5. I have already touched on the means of action of the organizations - much more than the proverbial desk and fax machine (see Point 1. and Points A and $\mathrm{B}$, above). The means play a major role in the coordination of actors in organizations; they serve, in the form of a relatively stable framework, as an identifiable representation by which the agents implicitly reconstitute the social bonds that have been established; and thus form ensembles or devices of habit that also facilitate the forgetting of the continuous institution of organizations by the power in common. If quasi-characters refer obliquely to the interactions of individual agents, it is because the relaying of their actions by technical devices makes this possible (in the same way symbols do). ${ }^{64}$ At the same time, this instrumental aspect of organizations prolongs the effect of augmentation and reduction of action: a city library, capable of offering a large collection to its readers, will be incapable of bringing these books to the readers; the mobile library, in order to maintain its mobility, will have to forego a large collection. Finally, whereas the material and organizational infrastructure of organized action can never sufficiently account for the agency of organizations, it certainly is a key point where the organization remains irreducible to the behaviour of the agents which function in it.

62 See again Chapter $3, \S 1$

63 This example is drawn from Robbins and Judge, Essentials of Organizational Behavior, 290. 64 Cf. Régis Debray on transmission in Chapter 1 and Anthony Giddens on "time-space distantiation" in Chapter 5. 


\section{Conclusion. Paradoxes, Risks, and Political Implications of Organized Action}

In this chapter I have tried to clarify the notion of organized individual and collective action. The relationships of capability and incapability involved in the action of the quasi-characters that are organizations were also examined. Nowhere have I simply equated organizations to agents writ large. Yet, the structural similarities between the (in)capable agency of individuals and organizations justifies a transfer of other conclusions from individual agency to this discussion of collective agency. In both cases, (in)capability is a feature of the finitude of agency. Moreover, the flip side of this is the situatedness of agents, both individual and collective. Then, incapability functions as the practical horizon of intelligibility of action in both cases. Finally, in the course of action, the shifting difference between capability and incapability remains uncertain, until executed actions have marked that difference. ${ }^{65}$ These four characteristics together help us to understand action as action and to appreciate the interpretative make-up of action. These are all aspects of the technicity of collective action, the study of which can clearly benefit from a hermeneutic approach.

Agents know practically that their capabilities to do things are shadowed by incapability. Every attestation of capability is an affirmation of an inability to do otherwise. Hence the impression - often obscured in more routine actions - that something can go wrong, that there is something at stake in action. This is certainly also true for organized action. In conclusion, I would like to highlight this point by looking at the paradox of organized action and the concept of risk.

65 Interestingly, despite my affirmation of two types of organizational agency (individual and collective) the cumulate effect of the five incapabilities, as they bear on capabilities, is to relativise the agent as the core of initiative and power. Accordingly, this draws a picture of power as more diffuse than my terminology of agency may have suggested. My exposition shows that power arises primordially "from below"; it has a relational structure, and the myriad of interactions generate shifting fields of power. At the same time, it accounts for the "crystallization" of power as effects of many interactions, which in turn account for concentrations of power (as in revolutions or states) and, more generally, the formation of power hegemonies. All these terms are directly derived from Michel Foucault's theory of power, or at least in its reformulation in Michel Foucault, Histoire de la sexualité 1. La volonté de savoir (Paris: Gallimard, 1976), 121-29. The most important difference seems to reside in the fact that I do not shy away from directly examining and theorizing the agency of powerfully organized action. 


\subsection{The Paradox of Organized Action}

This analysis of the (in)capabilities of organizations can help us to understand better the complex relationship between the intentions of agents, the plans of organizations and the whole range of adverse effects that accompany individual and collective action. ${ }^{66}$ For this reason, I argue that this general interplay of capabilities and incapabilities in collective action is the basis from which a more pronounced paradox emerges: where organization consolidates the power of people to act in common always lurks the likelihood that the organization may generate unintended, adverse or detrimental effects. This is not a declaration of an a priori pessimism about organizations. I simply underscore the unavoidable (but still varying and partially malleable) ambiguity of action in common.

In a previous chapter (Chapter $3, \S 5$ ), I have already argued for a general paradox of the technicity of action. If there is a paradox of organized action, it is due to the technical constitution of organized action ("technical" in the sense developed in this chapter). If the basic structure of the paradox of organized action then also corresponds with what Ricœur calls the political paradox (discussed in the Introduction, §3.2), it is because the political paradox is a particular manifestation of the broader paradox of organized action and the latter of an even broader paradox of the technicity of action. There is a paradox in each of these cases, because the power, abilities, initiative and means that make it possible for individual or collective agents to achieve certain things (bring forth a product, results, outcomes), can turn against the initial spirit and intention of the action. In the case of organized action, the instituting work by which a plurality of actors become capable of stabilising, consolidating and giving effect to their power in common can in turn veer away from the project or plan for which the collective action was organized, or can even stifle the sources of its power to which organizations obliquely refer. Thus organization can lead to forms of disempowerment or decapabilisation (as I illustrate in the Conclusion, §2).

There is no theoretical solution for this paradox; provisional compromises can only be found in practice. The ability to avoid the worst to emerge from this paradox is itself a sliding point on the spectrum of (in)capability. In the context of his discussion of the political paradox, Ricœur advocates compromises that reflect an "ethics of limited violence". The challenge of democracy, he says, is to find "the techniques" or "technologies" to make the exercise of power possible and abuse impossible. For organized action, broadly speaking,

66 Unintended consequences are explored further in Chapter 5, §3.2 (Point 2). 
I would say, the stakes are the continuous trade-off between norms and efficiency. This means that the only way by which to steer organized action to safety from the more harmful possibilities entailed in the paradox of organized action is by other organized action, which is equally subject to paradox. This is explored further in the chapters of Part II of this book.

\subsection{Organized Action in the Social Sciences}

As I have pointed out, the uncertainty involved in the relation between incapability and capability and amplified by the paradox of organized action leads us directly to the phenomenon of risk. The problem of risk magnifies the fact that, in action, something is at stake. I do not intend to open a larger discussion of this topic here. Rather, I want to show how the terms developed in this chapter can help to clarify the notion of risk even beyond the theoretical frame I have adopted, in other words also within discussions that respond to other theoretical commitments.

It is well known that Ulrich Beck gave an important impetus to the social scientific research and theorization of risk in his book Risk Society. ${ }^{67}$ Let us translate one of the main theses of this book into the terms proposed here and extend it to some conceptual implications not found in Beck's argument. Whatever the definition of "risk", this term implies the relationship between the capability to act and an inability to prevent, or even cope with, the consequences that result precisely from putting this capability into practice. A "risk society" would be a quasi-character that is constituted (a) by recognizing its social (in)capabilities by "second-degree reflection of the order of reconstruction", ${ }^{68}$ (b) a reconstruction centred on the category of risk, attributed to society as its salient contemporary characteristic, and (c) where risk brought to light by the social scientist. But risk(s) also say(s) something about the context of society, in particular, the urgency of a collective response. The transition from a class society to a risk society corresponds to a change in the internal arrangement of participation of the members of society.

In order to respond to the risks generated by modern industrialization, society takes recourse to science - yet another quasi-character. On the one hand, science is characterised by an increased capacity for interpretation and relevant advice to society - so much so that it would benefit from a "monopoly of

67 Ulrich Beck, Risk Society: Towards a New Modernity (London: Sage, 1992).

68 My translation, Ricœur, Parcours de la reconnaissance, 223 / Course of Recognition, 140. 
definitions" (this extraordinary capacity of science is matched by a widespread incapacity of other members of society). On the other hand, the complexity of the causal relationships revealed by science makes it impossible for it to rationally control the complexity of the consequences of planned actions on which it must express its expert opinion.

The point that risk is not a priori an evil is defended later by Niklas Luhmann. ${ }^{69}$ Whereas a danger is a possible disaster of which agents are unaware, a risk would be a danger that has been acknowledged, it is integrated into the calculated sphere of response (the inability to master the consequences of actions impromptu leads to an increased capacity for awareness). Thus an increased capacity to identify risks would increase the ability to respond to world events in a decisive manner.

More recently, Elísio Macamo ${ }^{70}$ has identified a whole series of questions relating to the "monopoly of definition" of risks, the importance of which can be gauged, for instance, in the context of humanitarian interventions in so-called developing countries: who defines the risk? for whom? in the name of which concerns? in relation to which emergency measure? etc. One could describe the spirit of Macamo's project as a study of the politics of allocating risk to quasi-characters. Furthermore, if risk identification is a factor that makes actors capable of (re)acting (Luhmann) and if the whole society is marked by the role of risks (Beck), then quasi-characters specializing in risks - the sciences, consulting firms, sometimes non-governmental organizations, etc. - could become disproportionately important in the exploration of the phenomenon of risk, to the detriment of the general public/agents. Hence the forgetfulness, or even ignorance, that Macamo notes among many researchers about the issue of risk among individual agents, or in regions of the world that have limited mastery of Western science (hence the importance of intercultural dialogue and negotiations as opposed to unilateral impositions that I touched on at the end of Chapter 2, and that is thematized in Chapter 6, $\S \S 5$ and 6). Thus, Macamo indicates the passage from incapability to fragility and suffering, and suggests the social-critical potential of studying risk.

69 Niklas Luhmann, "Die Moral des Risikos und das Risiko der Moral," in Risiko und Gesellschaft. Grundlagen und Ergebnisse interdisziplinärer Risikoforschung, ed. Gotthard Bechmann (Opladen: Westdeutscher Verlag, 1993), 327-38.

70 Elísio Macamo, “Conclusion,” in Risk and Africa, eds. Lena Bloemertz, Martin Doevenspeck, Elísio Macamo and Detlef Müller-Mahn (Vienna, Berlin: LIT Verlag, 2012), 265-72. 